\title{
Contemporary China-Japan Relations: the Politically Driven Economic Linkage
}

\section{Min-Hua Chiang ${ }^{1}$}

Received: 1 August 2019 / Accepted: 23 October 2019/Published online: 16 November 2019

(C) Springer Nature B.V. 2019

\begin{abstract}
This article presents the importance of political factors in the development of ChinaJapan economic relations over the last four decades. The China-US reconciliation and the rise of the pro-China Japanese Prime Minister Tanaka Kakuei (1972-1974) led to the normalization of China-Japan relations in 1972. The bilateral political rapport was further consolidated in the face of the common threat in the Soviet Union. With the strengthening political relations, the bilateral economic exchanges were gradually developed. Nonetheless, following the collapse of the Soviet Union, mounting SinoUS tension, China's growing assertiveness, and rising nationalism in both China and Japan, the Sino-Japanese bilateral political relations have been deteriorating. The escalating political tensions have impacted bilateral economic relations, including declining Japanese investment in China, weakening bilateral trade, and decreasing Japanese visitors to China. Despite improving bilateral political relations in recent years, it is uncertain how long these friendly gestures by the leaders of the two countries may last given several unsettled territorial and historical issues. The growing tension between the United States and China further adds uncertainty to China-Japan relations in the future. Without strong political relations, weakening economic ties cannot be easily restored.
\end{abstract}

Keywords China-Japan relations · Japan's investment in China · China-Japan tourism exchanges $\cdot$ China-Japan trade exchanges

\section{Introduction}

The political economists have long debated whether the China-Japan economic interdependence would result in peaceful political relations. The liberalists argued that the economic interdependence has repeatedly fostered the de-escalation of Sino-Japanese

Min-Hua Chiang

eaicmh@nus.edu.sg

1 East Asian Institute, National University of Singapore, 469A Bukit Timah Road, Tower Block\#06-01, Singapore 259770, Singapore 
conflict over territorial and maritime issues [33]. The close economic ties also provided a balm in times of trouble and were a foundation for bilateral political relations. However, the deepening economic interdependence did not lead to an eventual resolution of their political divide [13, 18, 60, 61]. Although the growing economic interdependence is a key incentive for maintaining peaceful relations, it is certainly not a sufficient condition for both sides to avoid armed conflict [15]. Arguably, the political dispute between China and Japan could have been even worse if there were no close economic ties. For the realists, China's rise and Japan's relative decline will inevitably result in the deteriorating of Sino-Japanese relations [56]. Given China's growing economy, the Sino-Japanese political dispute could be explosive if China used its economic power towards sanctions against Japan.

The tense political relations have shown signs of improvement in recent years. The foreign ministers from both countries expressed a willingness to improve relations as early as in 2016 [8]. During the G20 Summit in July 2017, Chinese President Xi Jinping and Japan's Prime Minister Shinzo Abe agreed to enhance bilateral exchanges. The friendly political relations encouraged both sides to strengthen institutionalized economic relations. In April 2018, the Japan-China High-Level Economic Dialogue, established in 2006, was held for the first time since 2010. During his visit to Japan in May 2018, Chinese Prime Minister Mr. Li Keqiang announced that China will grant Japan 200 billion yuan (US $\$ 31.3$ billion) of investment quota for the Renminbi Qualified Foreign Institutional Investors programme. Numerous cooperation agreements were signed across a wide range of fields covering investment, social security, and cultural exchange [2]. During Abe's visit in Beijing in October 2018, a 3-year currency swap agreement of up to 3.4 trillion yen (US\$30.4 billion) was signed. According to the Bank of Japan, the deal was designed to enhance the financial stability of the two countries. China and Japan also pledged to increase their cooperation in the area of innovation and infrastructure development in developing countries [23].

Unlike the progress in political relations, the Sino-Japanese economic ties have been fading. The statistics from the Japan External Trade Organization (JETRO) showed that Japan's investment in China gradually declined from its peak of US $\$ 13.5$ billion in 2012 to US $\$ 10.8$ billion in 2018. China's official statistics indicated that foreign direct investment (FDI) from Japan decreased from nearly US\$20 billion in 2013 to US\$9.8 billion in 2018. Japan was once the most important foreign investor in China, accounting for $8 \%$ of China's total FDI in 1995. The ratio declined to $3 \%$ in 2018 [10]. Sino-Japanese total trade also decreased from US\$345 billion in 2011 to US\$270 billion in 2016 and increased slightly to US $\$ 317$ billion in 2018. As most Japanese people went to China for business, the shrinkage in bilateral commercial exchanges resulted in the falling number of Japanese visitors to China from 3.7 million in 2011 to 2.7 million in 2018 [10].

The improvement in political rapport and more distant economic relations have challenged the traditional metaphor- "hot in economics and cold in politics" in describing China-Japan relations. Instead, the recent development showed that ChinaJapan relations have been moving toward "cold in economics and warm in politics". How can we explain such transformation in China-Japan relations? How the bilateral political and economic complexities have influenced each other in China-Japan relations over the last few decades? Will the warmer political relations help to improve their economic ties? Will the loose economic ties constrain the development of their political relations in the future? 
Beyond the US-China reconciliation in the 1970s, the visible economic benefits were another incentive for realizing China-Japan diplomatic normalization. However, the ever-increasing economic interdependence over the last 40 years has not prevented a number of political disagreements from repeatedly affecting Sino-Japanese relations. This shows the limited effect of economic ties on repairing political discrepancy. On the contrary, the political conflict seems to have impacted on the economic relations more obviously. Due to the widespread call to boycott Japanese goods after territorial disputes in 2012, the sales of many Japanese-branded products in China, notably cars and electronic goods, were impacted $[48,55]$. The economic effect from long-term political antagonism goes beyond the short-term market reactions. This explains the slowdown of Japanese investment in and trade with China in recent years. In short, the close economic connections were based on the strong political commitment to maintain a good relationship. With the changing geopolitical environment, the bilateral political ties are weakening. The Sino-Japanese economic relations have been gradually waning as a result.

The China-Japanese relations are worth studying as they are the two largest economies in Asia. The GDP of the two countries combined is $65 \%$ of region's total GDP [25]. ${ }^{1}$ As such, the development of Sino-Japanese relations is critical to the regional economic stability. The amicable relations between China and Japan would enhance the regional economic cooperation. On the other hand, the impact on the whole region would be influential if the political tension turned out to be economic chaos. Although both sides have restrained from furthering tensions so far, the sources of conflict, such as historical issues and territorial disputes, have remained. In addition, with China's economic rise and the strengthening military might, East Asia's political economic structure that relied on Japan's advanced industrial inputs and the US for national defense may be changed. Hence, the changing China-Japan relations not only have profound implications for the region but also for the global power structure. The study on the development of China-Japan relations provides an important empirical case in advancing international relations theory.

This paper attempts to offer a comprehensive understanding about the political factors in the development of Sino-Japanese economic relations. The timeframe is set from the establishment of bilateral diplomatic relations in 1972 to the present. The economic relations discussed in this article include Japan's investment in China, bilateral trade, and tourism exchange. The arguments presented in this paper are organized as follows: first, China-Japan economic relations were based on the strong political ties established in the $1970 \mathrm{~s}$. Several official agreements were signed to promote bilateral economic relations. Without the political leaders' initiatives, SinoJapanese economic relations would not be smoothly connected. Second, the bilateral political relations have experienced dramatic changes since the collapse of the USSR and the rise of China. Other reasons such as the countries' leaders' different political perceptions, China's greater economic power, and growing nationalism in both China and Japan also contributed to rising political antagonism. The increasing tense relations resulted in the slowdown of bilateral economic relations years later. In the third section, the impact from the escalating political tension on Japanese firms' investment in China

\footnotetext{
${ }^{1}$ The region includes 10 countries in Association of Southeast Asian Nations (ASEAN), Taiwan, South Korea, Japan, China, India, Australia and New Zealand.
} 
is examined. Fourth, as a result of Japan's FDI dip, Sino-Japanese trade exchange has slowed down. With China's economic advancement, the goods traded between the two countries have also evolved. Fifth, Japanese visitors to China have declined as a result of slowdown in Japanese FDI in China and bilateral trade. On the contrary, China's huge population and booming economy have made it become an important source of inbound tourism for Japan. Unlike Japan's business-driven outbound tourism, China's outbound tourism has been used as a tool in China's foreign policy to sanction against the recipient's economy [3]. As such, Japan's reliance on China as a main source of its inbound tourism posed a challenge to its tourism industry's development in the long term. Sixth, the US role in China-Japan relations is assessed. Good political relations are supposed to bring the two countries closer economically. Nonetheless, the duration of friendly political relations is uncertain due to the uncertain geopolitical environment, notably the power struggle between the US and China. Finally, the paper concludes with major arguments raised in previous sections and prospects of China-Japan relations in the future.

\section{Geopolitical Significance in China-Japan Economic Relations: an Overview}

A brief overview of Sino-Japanese relations demonstrates the geopolitical essence in the bilateral economic rapport after World War II (WWII). First, the Sino-US political conflict after the war prevented Japan from setting up economic exchanges with China. Japanese leaders in the 1940s and 1950s considered its economic revival depended on its exclusive access to Chinese resources and to the Chinese market [61]. Since China had been Japan's main commercial partner before the end of the WWII, it was understandable that Japan would like to reconstruct its damaged domestic economy by making economic contact again with China after the war, especially when the availability of supplies from pre-war colonies in Korea and Taiwan was limited. The Communist leaders in China also favored trade with Japan as a way to gain foreign exchange reserves and advanced technology as well as to reduce full dependence on the Soviet Union. Nevertheless, the intention to re-establish economic linkage between the two countries after the war was severed by the US. The Americans were concerned that Japanese political ties with the US would be negatively affected if Japan did not depend entirely on non-communist countries for trade. The US was also worried that the resumption of Sino-Japanese trade after the war would strengthen the military might of Communist China and even that of the Union of Soviet Socialist Republics (USSR) [42]. Even though Japan was reluctant to cut its contact with its former Chinese commercial partner, it could only accept it to bring to an end of the American occupation and to have a rapid access to the American market [44]. When Communist Party of China (CPC) criticized Japan more and more and the Sino-Soviet Treaty of friendship in 1950 was largely aimed against Japan, the Japanese leaders could only admit that its security and future development were guaranteed by the intimate alliance of the dominant American power in the region.

Second, the China-US rapprochement since the 1960s created an opportunity for Japan to re-establish its economic relations with China. Due to the unpopular war in Vietnam, the international environment that favored recognizing the People's Republic 
of China (PRC) and the need to deter the Soviet Union's power expansion, the deterrence of CPC did no longer match with new American interests. The ChinaSoviet split and the Chinese longing for Western capital goods, technologies, and economic development offered the US an opportunity to realize this diplomatic strategy. Other than the changes in the geopolitical situation, Japan saw trade as contributing to China's economic development and preventing a possible social and political collapse within the country. Supporting China's integration into the global community could also help to mitigate the popular nationalist hostility against Japan [61]. Moreover, Japan considered that close commercial ties with China would help the latter to transform into a cooperative partner [17]. From China's perspective, economic exchange with Japan would benefit its own economic development, thus helping to stabilize the country under the CPC's rule [61]. After the establishment of diplomatic relations in 1972, a series of policy measures were enacted to strengthen bilateral economic ties, including resuming bilateral trade, encouraging Japan's investment, and launching Japan's financial aid to China.

The strengthening bilateral economic relations were interrupted by the Tiananmen Incident in June 1989. Unlike most of the Western countries, Japan's sanctions against China did not last long. The business travel bans to China imposed in June 1989 ended in September of the same year. Financial loans to China resumed in November 1990. Japanese officials considered China too large to ignore. Besides, Japan was concerned that economic sanctions would strengthen China's hardliners and slow down necessary reforms. Eventually, China's political instability and economic stagnation would jeopardize the region's economic prosperity and peace $[60,63]$.

Despite the disputes from time to time over the historical and territorial issues, the leaders from both countries still tended to remain their political relations firm. For example, during Chinese President Jiang Zemin's visit to Japan in 1998, both sides signed the 'Japan-China Joint Declaration on Building a Partnership of Friendship and Cooperation for Peace and Development'. This is the third important document between the two countries, following the 1972 Joint Communiqué and the 1978 Treaty of Peace and Friendship. Mr. Shinzo Abe, in his first term as Japan's Prime Minister, made a fence-mending trip to Beijing in 2006. The Sino-Japanese Summit in 2006 confirmed the joint effort to build 'a mutually beneficial relationship based on common strategic interests. In late 2008, Japan's Prime Minister Tarō Asō singled his intention to continue improving ties with China. Overall, Japan's response to China's rise remained a strategy of engagement $[22,40]$. Meanwhile, China was aware of the impact of its emergence on the stability of regional political economy. Chinese leaders appreciated the importance of not being the dominant power in the world [46]. ${ }^{2}$ In the early $2000 \mathrm{~s}$, China still restrained itself from taking any further aggressive action so as to coincide with its 'peaceful rise' policy in order to counterbalance the 'China threat theory'.

After the mid-2000s, the Sino-Japan relations have been affected not only by the changing geopolitical situation but also Sino-Japanese competition for regional leadership. On one hand, US strategy has changed from countering the threat posed by the Soviet Union to responding to China's uncertain development. On the other hand, the

\footnotetext{
${ }^{2}$ The Chinese leadership followed the 24-character strategy, articulated by Deng Xiaoping. The direct translation for the 24-strategy is: observe calmly, secure our position, cope with affairs calmly, hide our capabilities and bide our time, be good at maintaining a low profile, and never claim leadership.
} 
growing disputes between China and Japan showed that Japan's strategy to transform China into a cooperative partner through economic means did not work. Japan has been struggling with its engagement policy towards China.

\section{Explaining the Rising Political Antagonism Between China and Japan After the mid-2000s}

The Sino-Japan political inconsistency became a more serious issue after the mid2000s. An anti-Japanese riot broke out in 2005 in many cities in China due to Japanese Prime Minister Junichiro Koizumi's visit to the Yasukuni Shrine, the Japanese government's approval of a revisionist textbook, and Japan's application for permanent membership in the United Nations Security Council. In 2010, SinoJapanese relations were stressed again when the Japanese Coast Guard arrested a Chinese captain after a Japanese boat collided with a Chinese trawler. In 2012, the Japanese government's purchase of the disputed Senkaku (Diaoyu) islands from the Kurihara family further irritated China. In May 2013, Japan refused to recognize China's declared Air Defence Identification Zone which covers the Japan-administered Senkaku islands. The political dispute has extended to the military front. In 2014, Chinese and Japanese military aircraft encounters in the disputed airspace over the East China Sea heightened tensions. In September 2015, Abe successfully pushed through security laws that would allow Japan's troops to participate in overseas combat missions. Its military spending in 2016 was aimed at countering Chinese military power expansion in the East China Sea and North Korea's missile threat [51]. At the same time, China also regarded Japan as a threat that needed Chinese military reaction. China's 2015 defense white paper stated that the US' 'rebalancing policy' in the Asia-Pacific region, Japan's changes in military policy, territorial disputes, the Taiwan issue, and terrorism are major concerns of the Chinese People's Liberation Army [5, 39].

The growing tension between the two countries can be attributed to a number of reasons. The first reason came from the changes in the geopolitical environment. With the collapse of the Soviet Union in the 1990s, there was no longer a need for China and Japan to stand united against a common enemy or to submerge their differences [1]. The US' increasing awareness of China's emergence also affected the Sino-Japanese relations. The US has played an important role in Japan's external relations since WWII. The bilateral security agreement since 1952 has allowed the US to establish its military presence in Japan's territory. In 1960, the revised US-Japan agreement granted the US the right to establish bases on the archipelago in exchange for a commitment to defend Japan in the event of an attack [35]. In 1997, the new US-Japan Defence Guidelines allowed Japan's military operations from its home islands to 'surrounding areas'. In 2005, the US and Japan explicitly identified the stability of the Taiwan Strait and the Korean Peninsula as common priorities for the first time and called on China to be more transparent regarding its military modernization [11]. While China perceived Japan's strengthening of its alliance with the US as limiting to its rise, the Japanese felt increasing diplomatic and military pressure from China. 
Second, the leaders' different perceptions about each other affected bilateral relations as well. Mao Zedong (1954-1959), China's founding father and the first chairman of the PRC, believed the CPC was able to come to power because of Japanese aggression against Nationalist China. Zhou Enlai, China's premier (1949-1976), studied in Japan and intended to improve relations with the country. Deng Xiaoping made Japan the model for China's development after seeing Japan's modernity on his visit to the country in 1978. Hu Yaobang also enjoyed a strong relationship of trust with Japan's Prime Minister Nakasone Yasuhiro (1982-1987). Unlike his predecessors, Jiang Zemin (1993-2003), who held personal bad memories about pre-war Japan, made a series of harsh remarks about historical issues [32]. Similarly, different Japanese leaders had dissimilar views towards China. Japan's Prime Minister Hayato Ikeda (1960-1964) had softened the Nubusuke Kishi government's (1957-1960) hard-line policy towards China as he considered Japan's overseas economic expansion a priority [63]. Prime Minister Sato Eisaku's (1964-1972) strong anti-China stance was a dampener to Sino-Japanese trade relations [9]. The rise of pro-China Prime Minister Tanaka Kakuei (1972-1974) contributed to the normalization of China-Japan relations in 1972. Bilateral ties went worse when Prime Minister Koizumi Junichiro (2001-2006) insisted on an annual visit to the Yasukuni Shrine [34].

Third, China's growing economic strength has posed challenges to Japan's influence in the region. In 1986, Japan's GDP was 7-8 times larger than China's. In 2010, China's GDP overtook Japan's, making it the second largest economy in the world, after the US. While the Chinese economy surged, Japan's economy progressed haltingly. In 2018, Japan's GDP was only 34\% of China's GDP (Fig. 1). Although Japan remains the leading high technology provider of other regional economies, China's move up towards high-end manufacturing might have squeezed Japan's other middle- to low-technology exports. In addition, China's economic development has been accompanied with its decreasing economic dependence on Japan. The country's strong reliance on Japan's technology, investment, and financial aid in the past might have

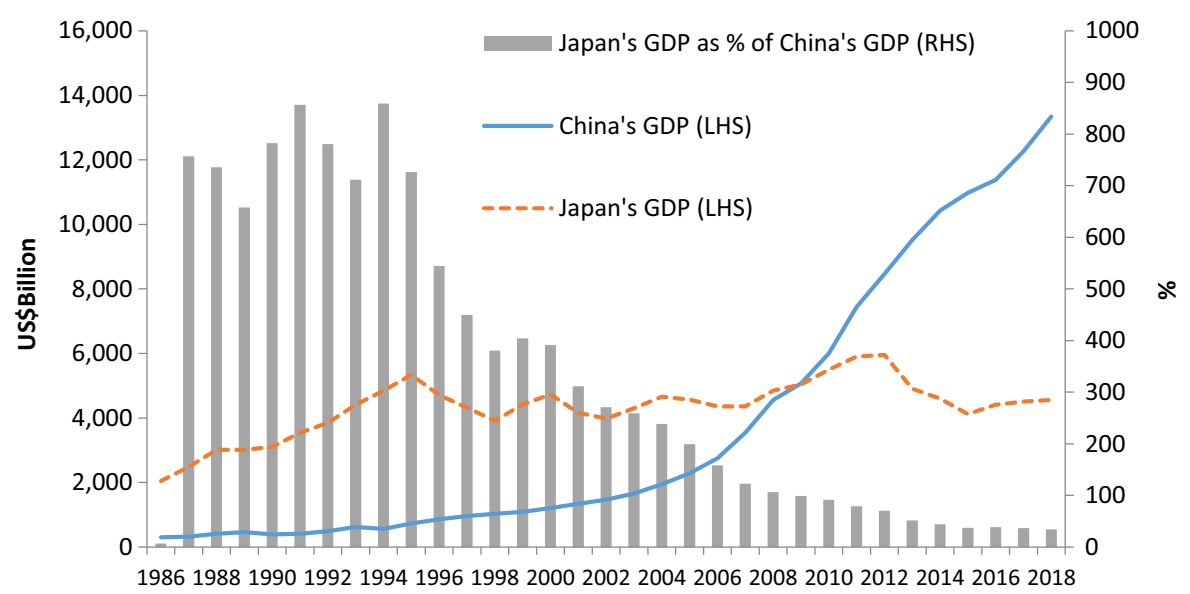

Fig. 1 Comparison of Japan's GDP and China’s GDP 1987-2018. Source: International Monetary Fund (2016) 
allowed it to leave political issues aside. However, with China's economic advancement, Japan has less leverage over China.

Fourth, growing nationalism contributed to their distrust and rivalry [20]. During the post-Cold War era, Chinese President Jiang Zemin emphasized a new kind of patriotism in which Japan's role was that of a cruel oppressor [61]. To legitimatize CPC's rule, the Chinese government put a new dimension of claims to the role of CPC as the upholder of China's dignity. Unlike China's nationalism, which is a product of and a response to the national humiliation during its history, Japan's nationalism towards China is a brand of anxietystricken nationalism that seeks to keep a sense of national superiority [62]. Lack of trust contributed to deteriorating relations at both the elite and popular level [43]. As bilateral frictions have grown over political and security issues, the national image that each country has of the other has worsened. A ChinaJapan joint survey in 2016 showed that $92 \%$ of Japanese and $77 \%$ of Chinese have "unfavorable impressions" of the other. Territorial issues and China's hegemonic actions are reasons behind Japan's unfavorable impression of China. For the Chinese, it was the territorial disputes and Japan's attempt to besiege China, as well as the lack of a proper apology over the military invasion that triggered their negative views towards Japan [57].

\section{Japan's Business Response: Investment Shift Away from China}

Beyond the government's policy initiatives, China's low wages, geographic proximity, and the yen's appreciation were encouraging factors for Japanese manufacturers' relocation of labor-intensive production to China [63]. China's greater economic liberalization following its entry to the World Trade Organization (WTO) in 2001 promoted a surge in Japanese investment. Total invested amounts increased significantly from US $\$ 0.9$ billion in 2000 to US\$6.6 billion in 2005 and US $\$ 12.6$ billion in 2011 (Fig. 2). Between 2002 and 2011, 60\% to 84\% of Japan's FDI in China was in

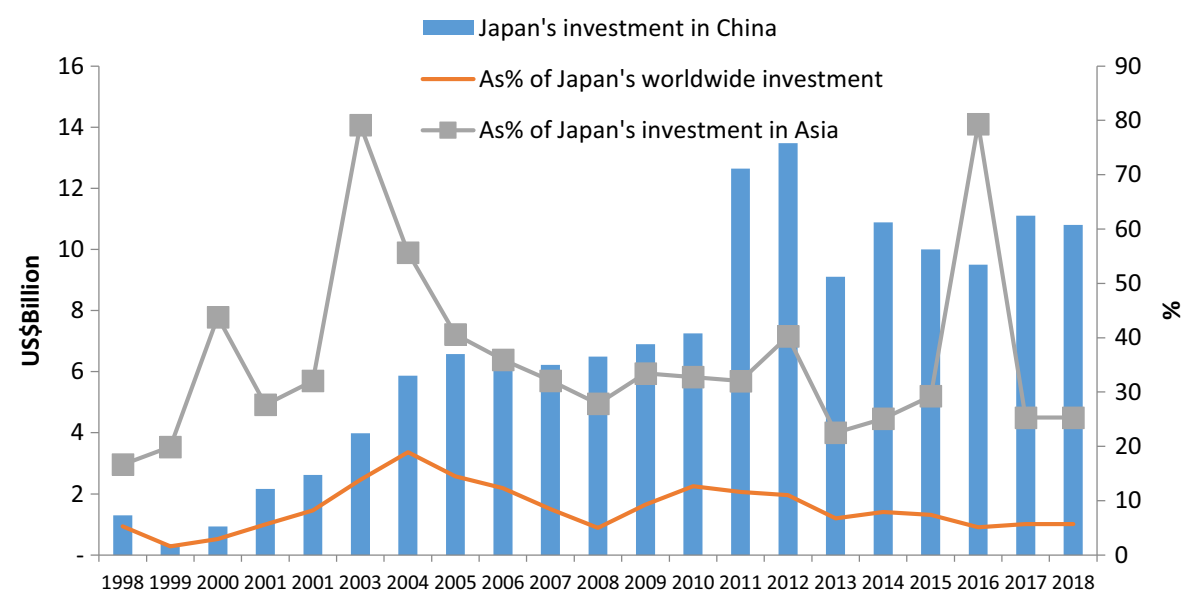

Fig. 2 Japan's investment in China 1998-2018. Source: JETRO 2018 
manufacturing sectors, according to China's official statistics [36, 37]. Nonetheless, Japan's FDI in China decreased to US\$9.1 billion in 2013 from its peak of US\$13.5 billion in 2012. During 2014 and 2018 period, Japan's FDI to China was waving between US $\$ 10$ billion and US11 billion annually (Fig. 2).

Japan's FDI in China is unlikely to have significant growth. JETRO's survey at the end of 2017 showed that $48 \%$ of Japanese firms indicated their willingness to expand their business in China in the next 1-2 years, declining from 67\% in 2011. The declining business sales in China is the main reason for the diminishing investment willingness cited in the same survey. Meanwhile, $44 \%$ of firms would keep the same business operations in China, increasing from 29\% in 2011. The willingness for business expansion differs across sectors. There is a higher percentage of firms in business services indicating their future business expansion plans in China (67\%). In comparison, the ratios for export-oriented manufacturing sectors are relatively low (53\%) [28]. This shows Japanese firms' response to the more consumption-based economic structure in China, instead of relying on China as an export platform.

Although JETRO's survey did not reveal any political factors, the worsening political relations should have played a significant role in explaining Japan's decreasing investment in China. First, unlike the robust growth from 2000 to 2005, Japan's annually invested amounts in China remained stagnant between 2005 and 2010, fluctuating between US\$6.6 billion and US\$7.3 billion during this period. The slow development of Japanese FDI in China came after a series of anti-Japanese demonstrations in 2005. China's share in Japan's total FDI in Asia declined gradually from $79 \%$ in 2003 to $41 \%$ in 2005 and $28 \%$ in 2008 . China's share in Japan's worldwide FDI also declined from $19 \%$ in 2004 to 5\% in 2008 (Fig. 2). China's smaller share showed Japan's investment shift to other countries.

Japan's investment in China rose in 2011 and 2012. The growth was related to Japan's FDI rebound worldwide. Apart from the yen's appreciation, Japan's earthquake and tsunami in March 2011 highlighted the need to relocate some factories overseas to minimize the risk of natural disasters. Despite the greater investment amounts in China, its share in Asia and in the world did not have significant changes during these 2 years.

After large-scale anti-Japanese demonstrations across different Chinese cities in 2012, Japan's FDI in China dropped sharply by $32 \%$ in 2013 to US\$9.1 billion. Japan's slow development of its investment in China indicates that until 2018, Japan's FDI in China has not yet recovered from the sharp decline following the anti-Japanese demonstrations in 2012. During the same period, Japan's total FDI in the world increased from US\$135 billion in 2013 to nearly US\$ 169 billion in 2018. With a relatively stagnant growth of investment in China, China's share in Japan's worldwide FDI fell from 13\% in 2010 to between 5 and 8\% during 2013 and 2018 period. Similarly, China's share in Japan's FDI in Asia also declined to $25 \%$ in 2018, from $40 \%$ in 2012 (Fig. 2). ${ }^{3}$

Japan's investment has been shifting to other parts of Asia, notably the developing countries in Southeast Asia. Since 2013, Japan's investment in nine countries from the Association of Southeast Asian Nations (ASEAN-9), including Vietnam, Malaysia, Brunei, Thailand, the Philippines, Indonesia, Laos, Myanmar, and Cambodia, has

\footnotetext{
${ }^{3}$ China's share in Japan's total FDI in Asia jumped to $79 \%$ in 2016 . The surge was attributed to the sudden decline of Japan's net investment outflow to Singapore so that China's share has robust growth.
} 
surpassed its investment in China. During the 2011-2018 period, Japan's total investment in China was US\$ 87.5 billion, smaller than its investment in ASEAN-9 (US\$144.5 billion) [29]. This is different from two decades ago when ASEAN countries were concerned about the FDI shifting away from ASEAN to China $[12,16]$.

Political factors can also be observed by comparing Japan's FDI to other countries' in China. China's official figures showed that from 2013 to 2018, Japan's FDI in China declined by nearly $60 \%$, the sharpest decline compared to other important investors in China, such as Taiwan (declined by 13.6\%), Singapore (declined by $27.5 \%$ ), South Korea (increased by $6.2 \%$ ), the US (declined by $15.5 \%$ ), and Germany (declined by $18.3 \%$ ) [10]. Economic factors such as China's wage hike and its economic slowdown have resulted in the decreasing inward FDI to China in recent years. The relatively sharp decline of Japanese investment in China implies that economic factors alone cannot explain it. The unsettled political disputes and two large anti-Japanese demonstrations have had significant impact on Japanese firms doing business in China.

\section{Changing Dynamics of the Sino-Japanese Trade Linkage}

After normalization of China-Japan diplomatic relations, several official agreements on trade, civil aviation, maritime transport, and fisheries were signed to regulate bilateral economic relations. The most noticeable is the Long-Term Trade Agreement (LTTA) signed in 1978 which was expected to meet the two countries' interests in trade [26, 63]. With China's greater economic opening up, the importance of LTTA in bilateral trade was substantially diminished. The market force based on the two countries' comparative advantage became the main driver behind the quick growth of bilateral trade since the 1990s.

Since the early 1990s, the development of Sino-Japanese trade relations has been largely driven by the Japanese firms invested in China. The China-based Japanese firms exported consumption goods to Japan after manufacturing in China [21, 63]. At the same time, they purchased capital goods and key components from Japan, which constituted a significant part of China's imports from Japan. Owing to Japan's greater import from than export to China, Japan has run a constant trade deficit with China since 1988 according to Japanese official figures. The deficit grew quickly from US\$0.3 billion in 1988 to its peak of US\$51 billion in 2013 and slowed down to US\$30 billion in 2018. Japan's trade deficit with China would become smaller if Japan's exports to Hong Kong were included.

As shown in Fig. 3, unlike the quick growth of bilateral trade during 1998 and 2008 period, both Japan's exports to and imports from China showed sluggishness since 2012. Several reasons explain the weakening trade linkage between the two countries. First, as most of Sino-Japan trade has been driven by Japan's FDI in China, Japan's decreasing investment in China has resulted in the slow development of bilateral trade. Although the trade figures showed a clear growth in 2010 and 2011 after the dip during the global financial crisis, it has dropped gradually since 2012.

Beyond Japan's declining investment in China, the higher ratio of local procurement made by China-based Japanese firms is another reason for the fewer imports from Japan. According to JETRO's survey in 2016, 68\% of Japanese companies in China procured raw material and industrial parts in China, against $58 \%$ in the previous year 


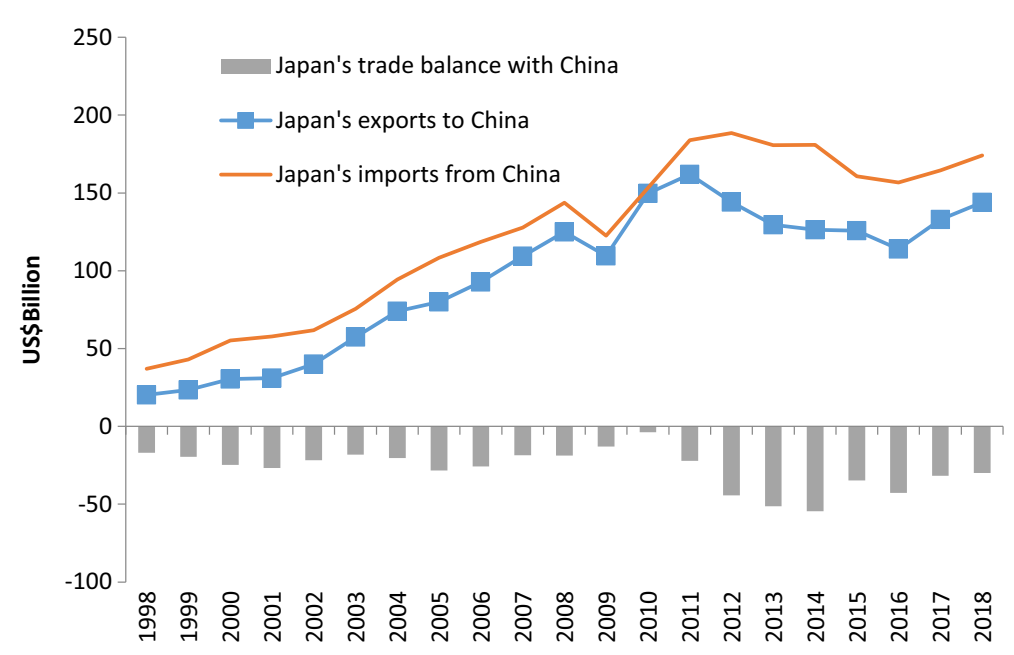

Fig. 3 Japan's trade relations with China 1998-2018. Source: CEIC 2018

and $43 \%$ in 2001 [7, 27]. The same survey showed that due to the lower cost, local Chinese companies are the largest source of procurement for Japanese firms in China, accounting for $59 \%$ of total responses, followed by $35 \%$ from Japanese affiliates and $6 \%$ from other foreign affiliates in China. Evidently, Japanese firms have established manufacturing alliances with local Chinese firms. Japan's trade deficit with China is less likely to be reversed as over $80 \%$ of Japanese firms in the survey responded that they will continue to procure local material for production in the future, the highest ratio compared to Japanese firms in other East Asian countries.

Third, Japan's FDI statistics showed a declining trend of manufacturing investment and growing importance of services in China over the last decade. The more China market-oriented investment in services (which does not require lots of manufacturing imports from and exports to Japan) could be another factor for the more distant SinoJapanese merchandise trade relations in recent years. Japan's FDI in China's services has increased from 23\% of its total FDI in 2006 to $39 \%$ in 2016. During the same period, the share of manufacturing investment declined from 78 to $60 \%$. Among the service sectors, the investment in wholesale and retail has the most noticeable growth (from 12 to $24 \%$ ) [6].

Finally, China's industrial upgrading also contributed to Japan's declining exports to China. China's industrial catch-up is reflected in the bilateral trade structure. In the 1980s, Japan exported mainly capital goods (e.g., machinery and electrical machinery) and metals to China in exchange for raw material and mineral fuels. In the 1990s and early 2000s, while Japan continued to export capital goods to China, the labor-intensive manufactured products (e.g., textiles) replaced raw material and energy as one of Japan's main import items from China. The shares of manufactured goods in Japan's total imports from China had clearly declined from 35\% in 1995 to $12 \%$ in 2015. Conversely, Japan's import of machinery and electrical machinery from China increased from 14\% in 1995 to $45 \%$ in 2015 (Table 1). Although machinery and electrical machinery still constituted the largest portion of Japan's exports to China, the country has imported even more of the similar products from China. This has resulted in Japan's 
Table 1 Japan's main import and export items with China 1980-2015. As \% of Japan's total imports from and exports to China

\begin{tabular}{lllllllll}
\hline & 1980 & 1985 & 1990 & 1995 & 2000 & 2005 & 2010 & 2015 \\
\hline $\begin{array}{l}\text { Japan's main import items from China } \\
\text { Textile (1995-2005)/manufactured goods }\end{array}$ & 12 & 15 & 27 & 35 & 30 & 17 & 15 & 12 \\
$\quad$ (2010 and 2017) & & & & & & & & \\
Machinery and electrical machinery & 0 & 0 & 4 & 14 & 26 & 36 & 43 & 45 \\
Foodstuffs & 11 & 14 & 16 & 13 & 11 & 7 & 5 & 5 \\
Raw material and mineral fuel & 67 & 59 & 33 & 10 & 7 & 5 & 2 & 2 \\
Others & 10 & 12 & 20 & 28 & 26 & 35 & 35 & 36 \\
Japan's main export items to China & & & & & & & & \\
Machinery and electrical machinery & 34 & 38 & 42 & 50 & 47 & 47 & 45 & 43 \\
Metals & 33 & 28 & 31 & 26 & 23 & 16 & 15 & 13 \\
Chemicals & 11 & 6 & 12 & 9 & 13 & 13 & 13 & 15 \\
Transport equipment & 8 & 17 & 2 & 4 & 4 & 5 & 10 & 9 \\
Precision instruments & 0 & 0 & 2 & 2 & 4 & 5 & 4 & 3 \\
IOthers & 14 & 11 & 11 & 9 & 9 & 14 & 13 & 17 \\
\hline
\end{tabular}

Source: Japan Statistical Yearbook, 1981, 1986, 1991, 1997, 2002, 2007, 2012, and 2016, Statistics bureau, Ministry of Internal Affairs and Communications, Japan [38]

trade deficit in machinery and electrical machinery with China, unlike the trade surplus on these items in 1995.

\section{Reversal in the Trend of Bilateral Tourism Exchanges}

Rising economic ties have promoted people-to-people exchanges, especially the growing number of Japanese businessmen to China. From the 1980s to the 1990s, the number of Japanese visitors to China made obvious progress. As shown in Fig. 4,

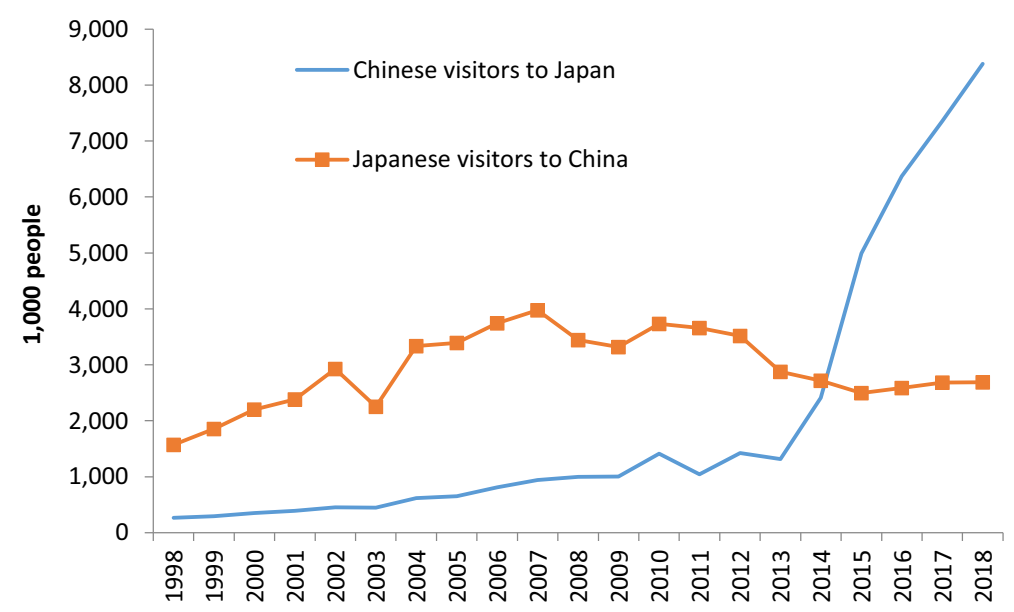

Fig. 4 Numbers of visitors between China and Japan 1998-2018. Source: CEIC 2018 
Japanese visitors declined during the Severe Acute Respiratory Syndrome (SARS) outbreak in 2003 and the global financial crisis during 2008-2009. The number of visitors rebounded in the following years after SARS and the financial crisis. However, after the anti-Japanese demonstrations in 2012, the numbers have clearly dropped from 3.5 million in 2012 to 2.9 million in 2013 and 2.7 million in 2017.

Japanese businessmen constituted the largest part of Japanese visitors to China. Hence, the decreasing Japanese investment in China caused the falling number of Japanese visitors to the country. According to China's official statistics in 2015, over a third of Japanese visitors went to China for business purposes. Only $16.4 \%$ went to China for leisure activities. Guangdong is the most visited place for Japanese visitors in China (19.9\%), followed by Shanghai (16.4\%) and Jiangsu (8.3\%) [41]. The geographic distribution of Japanese visitors corresponded to Japan's main investment destinations. Between 2001 and 2012, 54\% of Japanese investment in China was in Guangdong, Shanghai, and Jiangsu [36, 37]. Beyond political reasons, the declining number of Japanese visitors to China is also a result of Japan's weak economy. More than two decades of economic stagnation have dampened their travels abroad. The weaker Japanese yen is another factor. While it is a booster for foreigners' consumption in Japan, it made foreign goods more expensive for Japanese visitors abroad.

The growth of Chinese visitors to Japan was slow due to the bar to outbound tourism for private purposes. Japan also imposed restrictions on Chinese travellers going to Japan out of fear of illegal immigration [59]. Chinese government started to deregulate rules for Chinese citizens travelling to overseas countries since the mid-1990s. Residents in Beijing, Shanghai, and Guangzhou have been allowed to travel to Japan since 2000, followed by residents in Liaoning, Tianjin, Shandong, and Jiangsu since 2004. Since 2006, all Chinese citizens have been permitted to visit Japan. To respond to the increasing demands for Chinese, Japan has relaxed requirements for visas [49, 50].

Several political incidents caused declining numbers in Chinese visitors to Japan. In 2010, after the Japanese Coast Guard arrested a Chinese captain, China requested local travel agencies to halt Japan tourism advertisements [47]. Subsequently, Chinese visitors to Japan dropped from 1.41 million in 2010 to 1.04 million in 2011. After the quarrels over the Japanese government's purchase of five islands in the disputed Senkaku islands in 2012, Chinese visitors to Japan dropped again from 1.43 million in 2012 to 1.31 million in 2013. Improving relations is evidenced by the growing Chinese visitors to Japan, from 2.41 million in 2014, to nearly five million in 2015 and nearly 7.4 million in 2017. China is now Japan's largest source of inbound tourism and the most important contributor to Japan's inbound tourism receipts.

Japan is actively promoting its inbound tourism in recent years. As part of "Abenomics" policy, Prime Minister Shinzo Abe in 2014 set a goal of doubling the annual number of foreign tourists to 20 million in 2020. Following the quick growth of foreign visitors, the government in 2016 upped its target to 40 million visitors in 2020 and 60 million in 2030 [52]. China is likely to remain dominant in Japan's inbound tourist profile. Although China's economy has slowed down with an annual growth rate of below $8 \%$ since 2012, its outbound tourism had continued to register double-digit growth from 2012 to 2015 [4]. The relatively small portion of outbound tourists in its total population suggests China's great potential of contributing to Japan's inbound tourism. Therefore, smooth relations with China remains vital for Japan to maintain a steady growth of inbound tourists in the future. Furthermore, the greater inbound 
tourism expenditure could boost Japan's economic growth and become an important political advantage for Abe. Nonetheless, relying on Chinese tourists could leave Japan's tourism industry vulnerable to China's economic shocks and political uncertainties. The neighboring countries' experiences provided lessons for Japan. In 2017, South Korea's decision to deploy a US missile defines system angered China, the country's biggest trading partner, resulting in a sharp drop in Chinese tourists in Korea in 2017. The Chinese tourists in Taiwan, flourishing when KMT was in power, have declined sharply after Democratic Progressive Party (DPP) took power in Taiwan in 2016.

\section{Sino-Japanese Economic Relations in the New Context of Global Political Economy}

Despite improving diplomatic relations in recent years, the prospect of Sino-Japanese political rapport is still unpredictable. An important reason is geopolitical uncertainties, which are attributable to the dramatic US policy changes after President Donald Trump took office. On the third day of his presidency in 2017, Trump signed an executive order withdrawing the US from the Trans-Pacific Partnership (TPP), which he considered a bad deal for the US economy. In fact, the US joining TPP was a more strategic consideration rather than economic substance. TPP represented the economic dimension of the US' 'pivot to Asia' policy announced by the Obama administration in Fall 2011. Together with military and diplomatic dimensions, the US aimed to maintain its dominance in the region amidst China's power emergence. While China was actively involved in economic regionalization, TPP was an important offset to prevent China writing trade rules to its own advantage [58].

After the US withdrawal from TPP, Japan's strategy to balance China through USdominated multilateral economic cooperation was no longer workable. Japan was wary of China's ambitions in shaping the regional FTA framework through the Regional Comprehensive Economic Partnership (RCEP) [19]. The strategic and economic considerations motivated Japan to lead the development of TPP. In March 2018, the remaining 11 TPP countries signed the Comprehensive and Progressive Agreement for Trans-Pacific Partnership (CPTPP). On one hand, Japan can use the CPTPP to leverage the US request for trade liberalization. On the other hand, Japan can lead CPTPP to counterbalance China's growing dominance in the institutionalized economic integration [31]. On December 30, 2018, the CPTPP entered into force.

Aside from changes in institutionalized economic relations between the US and Asia, the market-driven economic linkages are about to be altered. President Trump blamed many of the US allies as the sources of America's growing trade deficit and pledged to amend the unfair trade for the US. Indeed, the US trade deficit is a result of its economic policy after WWII that aimed to consolidate its relations with its allies though economic means. Through large investment in overseas countries and the opening up of its market for foreign imports, the US has successfully made Asian countries rely on it for export-oriented economic development since WWII. The economic reliance allowed America to acquire strategic partners and consolidate its dominance in the region against the Communist regime's expansion. These security and economic relationships between the US and Asia have grown into a complex 
system of interdependencies [24]. Although many Asian countries today continue to rely on the US for export-oriented economic growth, America has seemingly lost its capability to manage the impact of globalization on its domestic economy. To revitalize the US economy, President Trump seeks to increase its exports and encourage more inward investments. If his policy works, it would significantly impact the economic order (Asia produces and America consumes) developed over the past few decades.

To reduce the US trade deficit, the Trump administration has revised FTAs with South Korea (KORUS) and Canada and Mexico (North American Free Trade Agreement, NAFTA) in 2018. Trade negotiations with Japan and the European Union (EU) are underway. With China, the US has imposed additional tariffs on Chinese products worth US $\$ 250$ billion since November 2018. In response, China has retaliated with tariffs on US products totalling US\$110 billion [54]. The US announced that new tariffs against all remaining Chinese imports (US\$257 billion) would be implemented if bilateral trade talks failed. The growing trade dispute between the US and China could weigh down on Japan's export prospects. Japan has been an important key component supplier for Chinese, Taiwanese, and Korean manufacturers in China. Thus, US trade retaliation against Chinese exports would indirectly affect Japanese exports to China. Several Japanese manufacturers announced they would shift their production site from China to Japan or other Southeast Asian countries in order to avoid the potential impact from the Sino-US trade war.

In the face of Trump's trade protectionism, China and Japan responded by tightening up their economic relations. Unlike the negative views towards China-backed Asian Infrastructure Investment Bank (AIIB) previously [14], ${ }^{4}$ Abe announced that he would be open to joining AIIB in May 2017. In June, he further announced that "Japan is ready to extend cooperation" with China's Belt and Road Initiatives (BRI). Japan might want to maintain its influence in the region through working with other developed countries in AIIB. Given Japan's strong desire for infrastructure export, Japan's participation in the AIIB is understandable [30]. Up to July 2019, AII has reached 100 members. Japan simply cannot ignore this multilateral organisation.

Beyond the cooperation in regional infrastructure development, both China and Japan are involved in regional economic cooperation such as RCEP and China-Japan-South Korea FTA (CJK FTA), which excludes the US. RCEP is an FTA between the ten member states of ASEAN, Australia, New Zealand, China, South Korea, Japan, and India. It is composed of nearly one third of the global GDP and almost half of the total world population. The CJK FTA, once established, will be the third largest free trade area in the world in terms of GDP, behind NAFTA and the EU. The CJK FTA will be especially noteworthy in Asia as the three countries account for $75 \%$ of the GDP in the region. On the whole, a unified regional market with liberalization in trade and investment is expected to make up for the impact of a slowdown in the American and European markets.

To counterbalance China's expanding power, President Trump proposed the 'Free and Open Indo-Pacific Strategy' (FOIPS) to replace TPP's strategic importance in the region. Similar to TPP, the FOIPS purports to counterbalance China's political, economic, and military challenges. The covered areas in FOIPS stretch from the western shores of the US to the west coast of India. The US, Japan, Australia, and India are core

\footnotetext{
${ }^{4}$ Since 2014, Japan and the US has persistently opted out of the AIIB or refused to endorse the Belt and Road Initiative (BRI). Japan viewed these initiatives as a challenge to ADB's leadership in regional infrastructure development and to other US-led international organisations in the global economy.
} 
countries in the strategy. Although Japan embraces Trump's FOIPS, it has a different version for FOIPS. Japan's FOIPS seeks to promote the rule of law at sea and build high-quality infrastructure in locations across the Indian and Pacific Ocean. Unlike the US' use of FOIPS to counterbalance China, Japan's version would welcome all countries, including China, to join in [55].

Despite the active involvement in RECP and CJK FTA, the depth of Sino-Japanese cooperation in regional economic integration may have its limit. The divided geopolitical interests between China and the US may restrain any further cooperation between China and Japan. Japan still relies on the US-Japan security alliance for its national security. Japan's defense budget in 2018 increased by $2.7 \%$ with an aim to counterbalance China's military expansion [10]. Its 2018 long-term defense guidelines express 'strong concern' over an 'uncertain regional security' situation posed by China's military expansion [45]. China may want to approach Japan amidst its political tension with the US. However, Japan's distrust towards China still exists. The Sino-Japan economic relations can hardly be improved without a stable and strong political foundation.

\section{Conclusion}

This paper attempts to contribute to the understanding of political factors in the development of Sino-Japan economic relations over the last four decades. The changing geopolitical environment in the 1960s and 1970s was the main pushing factor for the development of Sino-Japanese economic connections. The Sino-Japanese political relations went smoothly after the establishment of diplomatic relations in 1972 . The relatively strong political relations benefitted the progressive development of bilateral economic exchanges in the subsequent years. Bilateral trade, Japan's investment, and financial aid to China were the three tools in reconnecting the two economies. With China's greater economic opening up, market forces have replaced the governments' agreements in promoting bilateral economic ties.

Following China's economic development, Japan's FDI in China has transformed from export-oriented to domestic market-oriented. While Japan continued to supply capital goods and key components to China, China's exports to Japan have evolved, from energy resources in the 1980s to light manufactured goods (e.g., textiles) in the 1990 s and to heavy industrial goods (e.g., machinery and electrical machinery) after the 2000s. Close economic relations with Japan has been important for China's industrial catching-up and its transition from a low- to a middle-income country. For Japan, after the bursting of the asset-price bubble in the early 1990s, Japan's economic engagement with China has been important for energising its stagnant economic growth.

Since the 2000s, bilateral political relations have become increasingly conflicted. Changes in the global geopolitical environment (e.g., the fall of the USSR and growing Sino-US political discrepancy), the Chinese leaders' anti-Japan sentiment, China's growing economic power, and the clash of nationalism between China and Japan are factors behind the mounting political antagonism between the two countries. The impact on China-Japan economic relations from the persistent political clash is summarized as follows. First, the increasingly intensified political inconsistency has led to the sharp decline of Japan's FDI in the country. China's wage hike and economic transformation towards a more consumption-based economy are also factors for the decreasing FDI to China in recent years. Japan's relatively large investment drop compared to other major investors in China showed that political factors 
could have played a more important role than economic reasons in explaining Japan's falling FDI in China. Second, as bilateral trade has been motivated by the Japanese FDI in China, declining investments contributed to decreasing bilateral trade exchanges. China's industrial upgrading, Japanese firms' growing local procurement, and the investment shift from manufacturing to services are other factors for the weakening bilateral trade ties. Third, due to the slowing down of bilateral economic exchanges, Japanese visitors to China have a clear drop after 2012. On the contrary, China's outbound tourism is booming. Although the Chinese government restricted the number of Chinese visitors to Japan due to political quarrels from time to time, Chinese visitors to Japan grew after political disputes quieted down. Smooth relations with China remain vital for Japan to maintain a steady growth of inbound tourists in the future. However, the reliance on Chinese tourists could leave Japan's tourism industry vulnerable to China's economic and political changes.

Unlike realists' argument, China rise and Japan's relatively decline did not result in deteriorating relations. Instead, Japan seems to try to carefully accommodate China's rising power in recent years. Despite the signs of détente in bilateral relations, it is uncertain how long these friendly gestures could last. The unsettled territorial issues, historical legacy of World War II, and Sino-Japanese competition for regional leadership could be sources of conflict anytime. The unstable global political and economic situation, notably the power competition between the US and China, adds uncertainties to future Sino-Japan relations. China's active participation in global economic activities has enhanced its competitiveness in this increasingly interdependent world and enabled it to take part in reshaping the future global economy. The US has tried to pull back China's power expansion through economic, political, and military means. Economically, the US trade retaliation against Chinese products may affect local Chinese and foreign producers that demand Japanese industrial inputs. The Sino-Japanese production alliance could be affected by the US trade retaliation against Chinese products. Politically, the Trump administration proposed FOIPS to constrain China's rise in power. Japan has been cautious about the use of FOIPS to contain China. However, it may still feel uneasy about China's rise in power. More importantly, its security alliance with the US will continue to restrain any strategic cooperation with China.

In a nutshell, the weakening Sino-Japanese economic ties after 2013 is a reflection of worsening political relations since the mid-2000s. Despite the improving diplomatic relations in recent years, it is uncertain how the changing geopolitical environment, notably Sino-US discrepancy, will proceed and affect China-Japan relations in the future. ChinaJapan economic relations can only be restored and be prosperous with persistently strong political relations in the long run.

Acknowledgments The author would like to express her gratitude to the two anonymous reviewers' insightful comments and Mr. Philip Wang for reading the first draft.

\section{References}

1. Akio, Takahara. (2017). Forty-four years of Sino-Japanese diplomatic relations since normalization. In Lam Peng Er (Ed.), China-Japan relations in the $21^{\text {st }}$ Century: Antagonism despite interdependency (pp. 25-65). Singapore: Palgrave Macmillan.

2. Aoyama, Rumi. (2018). Commentary: China and Japan, a blossoming thaw after a decade of glim. News Article. Channel News Asia. https:/www.channelnewsasia.com/news/commentary/china-japanblossoming-thaw-after-a-decade-of-glum-10274008. Accessed 20 February 2019. 
3. Arlt, Wolfgang Georg. (2006). China's outbound tourism, London and New York, Routledge.

4. Arlt, Wolfgang Georg. (2015). China's outbound in 2015: another year of resilient growth and new trends. News Article. Forbes. http://www.forbes.com/sites/profdrwolfganggarlt/2015/12/30/2015-yearof-resilient-growth-and-further-segmentation-of-chinas-outbound-tourism/\#256712de1d46. Accessed 20 February 2019.

5. Bajpaee, Chietigj. (2016). Japan and China: The geo-economic dimension. News Article. The Diplomat. http://thediplomat.com/2016/03/japan-and-china-the-geo-economic-dimension/. Accessed 20 February 2019.

6. Bank of Japan. (2018). https:/www.boj.or.jp/en/statistics/boj/index.htm/. Accessed 20 February 2019.

7. Banri, Ito. (2012). How should we understand the economic impact of the soured relationship between Japan and China? Research Institute of Economy, Trade and Industry. http://www.rieti.go. jp/en/columns/a01_0358.html. Accessed 20 February 2019.

8. Blanchard, Ben. (2016). China, Japan more upbeat on ties but challenges remain. News Article. Reuters. https://www.reuters.com/article/us-china-japan-idUSKCN0XR02H(20. Accessed 20 February 2019.

9. Burns, Katherine G (2011). China and Japan: Economic partnership to political ends. Stimson Center. https://www.stimson.org/sites/default/files/file-attachments/china-japan-economic-partnership-politicalends.pdf Accessed 19 October 2019.

10. CEIC data company Ltd. (2018). https://www.ceicdata.com/zh-hans. Accessed 20 February 2019.

11. Chanlett-Avery, Emma and Rinehart, Ian E. (2016). The US-Japan alliance. CRS Report for Congress. https://fas.org/sgp/crs/row/RL33740.pdf. Accessed 20 February 2019.

12. Chia, S. Y., \& Sussangkarn, C. (2006). The Economic rise of China: Challenges and opportunities for ASEAN. Asian Economic Policy Review 1, 102-128.

13. Dreyer, June Teufel. (2014). China and Japan: hot economics, cold politics. Orbis, Summer, 326-341.

14. Editors of East Asia Forum (2017). Japan opens the way to cooperation on China's belt and road initiative. East Asia Forum. http://www.eastasiaforum.org/2017/07/10/japan-opens-the-way-tocooperation-on-chinas-belt-and-road-initiative/. Accessed 19 September 2017.

15. Fan, Ying (2017). Growing interdependency between China and Japan: trade, investment, tourism and education. In Lam, Peng Er (Ed.), China-Japan Relations in the $21^{\text {st }}$ Century: Antagonism despite Interdependency (pp.67-82). Singapore: Palgrave Macmillan.

16. Felker, G. B. (2003). Southeast Asian industrialisation and the changing global production system. Third World Quarterly, 24 (2), 255-282.

17. Green, Michael J. and Self, Benjamin. (1996). Japan's changing China policy: from commercial liberalism to reluctant realism. Survival, 38(2), 35-58.

18. Hagström, Linus. (2008). Sino-Japanese relations: the ice that won't melt. International Journal, 64 (1), 223-240.

19. Harding, Robin, Mitchell, Tom and Peel, Michael. (2017). China and Japan vie for control of Asia trade deal. News Article. Financial Times. https:/www.ft.com/content/d34d324c-03d8-11e7-ace0-1ce02ef0def9. Accessed 20 February 2019.

20. He, Yinan. (2013). Forty years in paradox: post-normalisation Sino-Japanese relations, China perspectives 4, 7-16.

21. Hilpert, Hanns Gunther. (2002). China and Japan: conflict or cooperation? what does trade data say?. In Hilpert, Hanns Gunther and Haak, Eene (Eds.), Japan and China: Cooperation, competition and conflict (pp.52-71). New York: Palgrave.

22. Hughes, Christopher W. (2009). Japan's response to China's rise: regional engagement, global containment, dangers of collision. International Affairs, 5(4), 837-856.

23. Hurst, Daniel. (2018). Abe wants new era in China-Japan relations. News Article. The Diplomat. https:/thediplomat.com/2018/10/abe-wants-new-era-in-china-japan-relations/. Accessed 20 February 2019.

24. Ikenberry, G. John. (2004). American hegemony and East Asia order. Australian Journal of International Affairs, 58(3), 353-367.

25. International Monetary Fund. (2016) World Economic Outlook Database. https://www.imf. org/external/pubs/ft/weo/2016/01/weodata/index.aspx. Accessed 20 February 2019.

26. Ishikawa, Shigeru. (2011). Sino-Japanese economic co-operation. In Caroline Rose (Ed.), Sino-Japanese relations: History, politics, economy and security (pp. 125-145). New York: Routledge.

27. Japan External Trade Organization (JETRO). (2016). FY 2016 JETRO survey on business conditions of Japanese companies in Asian and Oceania. https://www.jetro.go.jp/ext_images/en/reports/survey/pdf/rp_ firms_asia_oceania2016r.pdf. Accessed 20 February 2019.

28. Japan External Trade Organization (JETRO). (2017). FY 2017 JETRO survey on business conditions of Japanese companies in Asian and Oceania. https://www.jetro.go.jp/ext_images/en/reports/survey/pdf/rp_ firms_asia_oceania2017.pdf. Accessed 20 February 2019. 
29. Japan External Trade Organization (JETRO). (2018). Japanese trade and investment statistics. https://www.jetro.go.jp/en/reports/statistics/. Accessed 20 February 2019.

30. Tomoo Kikuchi and Wang Z (2016). The AIIB and shifting economic dynamics in Southeast Asia. News Article. Brink News. http://www.brinknews.com/asia/the-aiib-and-shifting-economic-dynamics-insoutheast-asia/. Accessed 19 September 2017.

31. Kim, Eunseo. (2018). The C PTPP and its implications for Japan. News Article. The Diplomat. https://thediplomat.com/2018/05/the-cptpp-and-its-implications-for-japan/. Accessed 19 October 2019.

32. Kokubun, Ryosei, Soeya, Yoshihide, Akio, Takahara and Kawashima, Shin. (2017). Japan-China relations in the modern era, London and New York: Routledge.

33. Koo, Min Gyo (2009). The Senkaku/Diaoyu dispute and Sino-Japanese political-economic relations: cold politics and hot economics?. The Pacific Review, 22(2), 205-232.

34. Lam, Peng Er. (2017). China-Japan paradox: antagonism despite interdependency. In Lam Peng Er (Eds), China-Japan relations in the 21st century: Antagonism despite interdependency (pp. 1-22). Singapore: Palgrave Macmillan.

35. Maizland, Lindsay and Xu, Beina. (2019). The US-Japan security alliance. Backgrounder, Council on Foreign Relations. https://www.cfr.org/backgrounder/us-japan-security-alliance. Accessed 18 September 2019.

36. Ministry of Commerce of People's Republic of China. (2011). China foreign investment report. Beijing: Economy and Management Publishing House.

37. Ministry of Commerce of People's Republic of China. (2013). Report on foreign investment in China. Tianjin: Nankai University Press.

38. Ministry of Internal Affairs and Communications (Japan). Japan Statistical Yearbook, various years.

39. Ministry of National Defence of the People's Republic of China. (2015). China's military strategy. http://www.mod.gov.cn/regulatory/2015-05/26/content_4617812.htm. Accessed 20 February 2019.

40. Mochizuki, Mike M. (2007). Japan's shifting strategy toward the rise of China. The Journal of Strategic Studies, 30 (4-5), 739-776.

41. National Tourism Administration of the People's Republic of China. (2015) The Yearbook of China Tourism Statistics. Beijing, China Travel and Tourism Press.

42. Nester, W.R. (1990). Japan's Growing Power Over East Asia and The World Economy. London: The Macmillan Press Ltd.

43. Rose, Caroline and Sýkora, Jan. (2017). The trust deficit in Sino-Japanese relations. Japan Forum, 29 (1), 100-124.

44. Schaller, M. (2002). The United States and China into the Twenty-First Century. New York: Oxford University Press.

45. Siripala, Thisanka. (2018). Japan's defense budget swells to counter China's growing military threat. News Article. The Diplomat. https:/thediplomat.com/2018/12/japans-defense-budget-swells-to-counterchinas-growing-military-threat/. Accessed 20 February 2019.

46. Smith, Paul J. (2009). China-Japan relations and the future geopolitics of East Asia. Asian Affairs: An American Review, 35(4), 230-256.

47. Source. (2010). China limits outbound travel to Japan. News Article. Travel Daily. http://www.travedaily. cn/article/44357. Accessed 20 February 2019.

48. Source (2012). Japanese Car Sales Plunge in China After Islands Dispute. News Article. The Guardian. October 9. https:/www.theguardian.com/business/2012/oct/09/japanese-car-sales-china-islands-dispute. Accessed 20 February 2019.

49. Source (2015). Japan Eases Visa Requirements for Chinese Applicants. News Article. China Daily, http://www.chinadaily.com.cn/china/2015-01/14/content_19318981.htm. Accessed 31 October 2016.

50. Source (2016). Japan eases visa rules for Chinese tourists to encourage return visitors. Asian Correspondent. https://asiancorrespondent.com/2016/09/japan-eases-visa-rules-for-chinese-tourists/. Accessed 21 December 2016.

51. Source. (2016). Japan's government approves record military spending. News Article. Reuters. http://www. reuters.com/article/us-japan-defence-budget-idUSKBN14B01C. Accessed 20 February 2019.

52. Source (2017). Tokyo Olympics fueling expectations of an economic boom and fear of a bubble. News Article. The Japan Times. http://www.japantimes.co.jp/news/2017/01/03/national/tokyo-olympicsfueling-expectations-economic-boom-fear-bubble/. Accessed 20 February 2019.

53. Source (2018a), Principles of Japan's Indo-Pacific strategy align with Singapore, ASEAN priorities: PM Lee. News Article. The Strait Times. https:/www.straitstimes.com/singapore/principles-of-japans-indopacific-strategy-align-with-singapore-asean-priorities-pm-lee. Accessed 20 February 2019.

54. Source (2018b). China says Xi-Trump phone call quite positive. News Article. The Strait Times. https://www.straitstimes.com/asia/east-asia/china-says-xi-trump-phone-call-quite-positive. Accessed 20 February 2019. 
55. Takada, Kazunori. (2014). Discretion pays for Japanese brands in China amid territorial dispute. News Article. Reuters. https:/www.reuters.com/article/us-japan-china-companies/discretion-pays-for-japanesebrands-in-china-amid-territorial-dispute-idUSBREA4K16M20140521. Accessed 20 February 2019.

56. Takeuchi, H. (2014). Sino-Japanese relations: power, interdependence, and domestic politics. International Relations of the Asia-Pacific, 14 (1), 7-32.

57. The Genron Non-Profit Organisation. (2016). The 12th Japan-China joint opinion poll analysis report on the comparative data. http:/www.genron-npo.net/en/opinion_polls/archives/5318.html. Accessed 20 February 2019.

58. Wallace, Corey. (2018). Leaving (north-east) Asia? Japan's southern strategy. International Affairs, 94 (4), 883-904.

59. Wan, Ming. (2006). Sino-Japanese relations: Interaction, logic and transformation. California: Stanford University Press.

60. Whiting, Allen S. (1992) 'China and Japan: politics versus economics. The Annals of the American Academy of Political and Social Science, 519, 39-51.

61. Yahuda, Michael. (2014) Sino-Japanese relations after the Cold War: Two tigers sharing a mountain. Oxon and New York: Routledge.

62. Yang, Lijun. (2017). A clash of nationalism: Sino-Japanese relations in the twenty-first century. In Lam Peng Er (Eds.), China-Japan relations in the 21 ${ }^{\text {st }}$ century: antagonism despite interdependency (pp.83101). Singapore: Palgrave Macmillan.

63. Zhang, Dong Dong. (1998). Negotiating for a liberal economic regime: the case of Japanese FDI in China. The Pacific Review, 11(1), 51-78.

Publisher's Note Springer Nature remains neutral with regard to jurisdictional claims in published maps and institutional affiliations. 